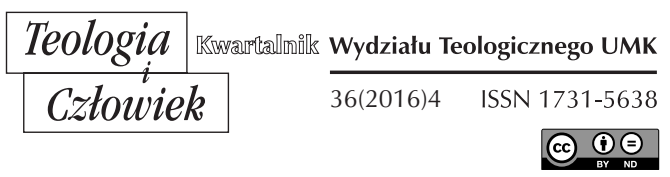

KS. HENRYK SŁAWIŃSKI*

KRAKÓW

\title{
PRZEPOWIADANIE Z HUMOREM
}

DOI: http://dx.doi.org/10.12775/TiCz.2016.047

\section{WAŻNA ROLA HUMORU W ŻYCIU CZKOWIEKA}

Humor jest ważnym elementem ludzkiego życia. Wypełnia je nie tylko w chwilach radosnych, ale również dramatycznych. W lipcu 1993 roku klaun z Barcelony, Tortell Poltrona został poproszony przez grupę uczniów szkolnych o pomoc. Uczniowie korespondowali z dziećmi żyjącymi w obozie dla uchodźców w Chorwacji, które przeżyły wojnę w Jugosławii w latach 1991-1995. Dzieci z obozu napisały do uczniów z Katalonii, że tym, czego im najbardziej brakuje, to śmiech, radość i zabawa. T. Poltrona odpowiedział na tę prośbę i z grupą klaunów pojechał do tego obozu. Powitały go setki dzieci z rodzicami. Obóz dla uchodźców został wypełniony śmiechem i brawami. Gdy klauni odjeżdżali, pytano

* Henryk Sławiński - prezbiter, dr hab., profesor Uniwersytetu Papieskiego Jana Pawła II w Krakowie, homileta i pedagog. Wykładowca na Uniwersytecie Papieskim Jana Pawła II w Krakowie, w Wyższym Seminarium Duchownym w Tarnowie i w Wyższym Seminarium Duchownym Księży Misjonarzy św. Rodziny. Redaktor naczelny kwartalnika „Polonia Sacra”. Przewodniczący Stowarzyszenia Homiletów Polskich, członek Komisji Języka Religijnego PAN, koordynator współpracy zagranicznej Wydziału Teologicznego UPJPII z uczelniami we Francji i krajach Beneluxu (henryk.slawinski@upjp2.edu.pl) 
ich, kiedy znowu przyjadą. To doświadczenie dało początek organizacji Non-Profit „Payasos Sin Fronteras” - Klauni bez granic. Celem organizacji założonej przez T. Poltrona jest dostarczenie ludziom po traumatycznych przeżyciach humoru jako środka psychologicznego wsparcia.

Bardzo szybko organizacja rozszerzyła się na Szwecję i Francję. Pod wpływem T. Poltrony Moshe Cohen założył w Stanach Zjednoczonych w 1995 roku organizację Non-Profit "Clowns Without Borders" (CWB-USA) - Komicy bez granic. Organizacja ta koordynuje obecnie działalność federacji międzynarodowej „Clowns Without Borders International"'. W ciągu pięciu lat od powstania przeprowadzono ponad sto ekspedycji w wielu krajach. W 2007 roku powstała komórka organizacji w Niemczech. Obecnie „Clowns Without Borders” funkcjonują w dwunastu krajach i działają w regionach ogarniętych konfliktami wojennymi: od Sahary Zachodniej, przez Palestynę i Izrael, aż po Kolumbię. Wykonując komiczne sztuczki na wyspie Lesbos dla uchodźców o rozmaitym pochodzeniu, komicy zauważyli, że wszyscy w tym samym momencie klaskali, śmiali się, otwierali buzie ze zdziwienia. Wszyscy śmiali się w tym samym języku. Komizm jest językiem uniwersalnym. Komik, Clay Letson, posługujący się pseudonimem „Mazing” już przed 2005 rokiem zaangażował się w działalność „Komików bez granic”, a w 2012 roku założył działającą w Ameryce Północnej organizację publicznego pożytku „Emergency Circus”, której celem jest dostarczanie śmiechu ludziom w szpitalach, więzieniach, a także ludziom bezdomnym. Śmiech bowiem, będący reakcją na humor, posiada uzdrawiającą siłę, podnosi poziom endorfin w organizmie, zmniejsza stres, zmniejsza odczucie bólu i wywiera wspólnototwórcze oraz wychowawcze oddziaływanie. Po występie szwedzkiego zespołu „Klaunów bez granic” w jordańskim obozie dla uchodźców Zảatari jeden z pracowników stwierdził, że przed występem dzieci bawiły się w wojnę, po ich występie, dzieci bawiły się w klaunów² Humor wychowuje i łagodzi napięcia społeczne.

${ }^{1}$ Clowns without borders, http://www.clownswithoutborders.org/ (dostęp 20.06.2016).

2 A.S. Hofmeister, „Jeder lacht in derselben Sprache“, „Die Tegespost“ 72 (2016), s. 8 . 
Humor pełni wiele pożytecznych funkcji w życiu społecznym: pozwala, choćby na chwilę, zapomnieć o cierpieniu i uwolnić się od stresu w obliczu nabrzmiałych problemów, a ponadto może integrować ludzi $\mathrm{z}$ różnych narodów i kultur, i pozwala dostrzegać pozytywny wymiar życia. Nic więc dziwnego, że humorem zajmują się zarówno językoznawcy, jak i psycholodzy, a nawet teolodzy ${ }^{3}$. Jest on także przedmiotem zagranicznych opracowań homiletycznych ${ }^{4}$. Niestety w polskiej literaturze istnieje zaledwie jedno, niewielkie opracowanie na ten temat ${ }^{5}$.

Warto więc podjąć to zagadnienie i przeanalizować, dlaczego humor, pomimo swych pozytywnych walorów, spotykał się z ambiwalentną oceną, gdy chodzi o jego wykorzystanie w przepowiadaniu. W poniższym opracowaniu zostanie więc podjęta próba wykazania, że jest miejsce na humor i uśmiech w przepowiadaniu, innymi słowy, że ambona nie powinna być jedynym miejscem na świecie, w którym humor byłby zakazany. Najpierw więc zostanie bardzo krótko omówiona istota humoru, a potem dostarczone zostaną - na zasadzie videtur quod non - argumenty przemawiają przeciw jego stosowaniu na ambonie. Po nich zaś przedstawione będą argumenty przeciwne, czyli przemawiające za jego wykorzystaniem w przepowiadaniu. Całość zostanie zakończona krótkim podsumowaniem.

\section{ISTOTA HUMORU}

Humor to umiejętność uchwycenia inkongruencji czyli braku odpowiedniości, kontrastu i paradoksu. Humor oznacza też pozytywne i radosne podejście do świata połączone ze zdolnością dostrzegania ko-

${ }^{3}$ Por. Świat humoru, red. S. Gajda, D. Brzozowska, Opole 2000; S. Janeczek, K. Popielski, Humor, w: Powszechna Encyklopedia Filozofi, t. 4, red. A. Maryniarczyk i in., Lublin 2003, s. 669-672; W. Wołyniec, Humor, w: Leksykon duchowości katolickiej, red. M. Chmielewski, Lublin-Kraków 2002, s. 324-325.

${ }^{4}$ B.M. Berchmans, Umorismo, w: Dizionario di Omiletica, red. M. Sodi, A.M. Triacca, Torino-Bergamo 1998, s. 1640-1643; W.H. Willimon, Humor, w: Concise Encyclopedia of Preaching, red. W.H. Willimon, R. Lisher, Louisville, KY 1995, s. 262-264; J.W. Drakeford, Humor in Preaching, Grand Rapids 1986.

${ }^{5}$ E. Kucharska, W. Przyczyna, Czy podczas kazania jest miejsce na (u)śmiech, „Współczesna Ambona” 2 (2000), s. 184-189. 
micznych stron życia ${ }^{6}$. Francis Hutcheson (1694-1746) uważał, że źródłem humoru jest spostrzeżenie czegoś dziwacznego ${ }^{7}$. Z kolei Immanuel Kant (1724-1804) w dziele Krytyka władzy sądzenia z 1790 r. podkreślał w humorze element niespodzianki ${ }^{8}$. Wreszcie Henri Bergson (1859-1941) w swej książce z 1900 roku zatytułowanej Śmiech. Esej o komizmie uznał humor za obronę przed automatyzmem, który godzi w autentyczność życia ${ }^{9}$. Angielski eseista William Hazlitt twierdzi, że człowiek jest jedynym stworzeniem w całym świecie, które śmieje się i płacze, ponieważ jako jedyny „potrafi dostrzec różnicę między tym, jakie coś jest, a tym, jakie mogłoby być" ${ }^{10}$. Poczucie humoru jest wyrazem dojrzałości emocjonalnej i zrównoważenia psychicznego ${ }^{11}$.

Zdaniem jezuity, Jamesa Martina, humor „jest bardziej wartością lub cechą niż uczuciem. «Cechą, która odnosi się do wyczucia śmieszności lub absurdalnej niespójności», mówi Webster. Humor, dowcip czy wyczucie komizmu jest czymś, co można mieć albo w sobie wykształcić, nie mieć albo się nauczyć. Humor może być także nierozerwalnie związany z określonymi sytuacjami” ${ }^{12}$. Ponadto J. Martin zauważa, że humor może być dobry lub zły. Dobrym jest na przykład „żartowanie z samego siebie, żarty, które dodają otuchy, i takie, z których śmieją się wszyscy i których «ofiarą» nie czuje się nikt” ${ }^{3}$. Natomiast złym humorem są „żarty na temat rasy, płci czy narodowości, które są krzywdzące; wyśmiewanie się ze słabszych; przezywanie"14. Humor dobry buduje, zły burzy, poniża bezbronnych i lekceważonych ${ }^{15}$. Mówi się ponadto o „czarnym humorze”, ale nigdy o „białym”. „Czarny humor” pojawia się wtedy, gdy elementy komizmu występują w sytuacjach dramatycznych.

${ }^{6}$ Por. W. Wołyniec, Humor, s. 324.

7 Reflections on Laugter, „Dublin Journal” 1725 r.; cyt. za: S. Blackburn, Oksfordzki słownik filozoficzny, Warszawa 2004, s. 390.

${ }^{8}$ Por. S. Blackburn, Oksfordzki słownik filozoficzny, s. 390.

9 Por. tamże, s. 390.

${ }^{10}$ J. Martin, Między niebem a radością. Humor i śmiech sednem życia duchowego, Edyta Stępkowska, Kraków 2012, s. 74.

${ }^{11}$ Por. tamże.

12 Tamże, s. 24.

13 Tamże.

14 Tamże.

15 Por. tamże, s. 31. 
Cechą charakterystyczną dla humoru jest element zaskoczenia. Wynika ono z inkongruencji, czyli braku odpowiedniości. Jej najdoskonalsze przykłady zawierają element absurdu, w którym rzeczywistość zyskuje totalnie irracjonalne znaczenie ${ }^{16}$. Jako ilustrację John W. Drakeford przytacza następującą historię, która należy raczej do kategorii „czarnego humoru":

Ksiądz proboszcz pojechał do Afryki jako misjonarz i tam w czasie pełnionej posługi został zabity przez autochtonicznego asystenta. Chcąc uczcić zamordowanego proboszcza, członkowie Kościoła postanowili umieścić na ścianie kościoła tablicę pamiątkową z następującym napisem: „Na pamiątkę czcigodnego księdza Józefa Priora, naszego misjonarza, który pełniąc służbę dla Pana w Afryce, został zamordowany przez swego asystenta. «Dobrze, sługo dobry i wierny!» (Mt 25,23)"17. Humor powstaje przez możliwość dwuznacznej interpretacji słów albo też przez zestawienie ze sobą dwóch elementów, które, jak się wydawało wcześniej, nie miały ze sobą nic do czynienia.

Innym integralnym składnikiem humoru jest przesada. Jest ona bardzo często wykorzystywana $\mathrm{w}$ dramatach i opowieściach kryminalnych. Ich czytelnicy bądź słuchacze spodziewają się, że przestępcą będzie człowiek o złych cechach, a ku zaskoczeniu wszystkich, okazuje się nim być postać najmniej podejrzana ${ }^{18}$.

Humor zawiera w sobie zarówno elementy subiektywne, jak i obiektywne. O subiektywizmie świadczy fakt, że nie wszyscy ludzie mają jednakowe poczucie humoru i nie wszyscy równie błyskotliwie odszyfrowują inkongruencję w życiu. Natomiast o obiektywizmie humoru świadczy fakt, że w obiektywnie śmiesznych sytuacjach wszyscy jednocześnie wybuchają śmiechem. Można więc powiedzieć, że humorystyczne jest nie tylko to, co człowieka uważa za humorystyczne, ale to, co samo w sobie jest humorystyczne ${ }^{19}$.

Po zwięzłym wyjaśnieniu istoty humoru możemy przypomnieć postawiony we wstępie problem: czy można wykorzystać humor w prze-

16 Por. J.W. Drakeford, Humor in Preaching, s. 60.

17 Por. tamże, s. 61.

18 Por. tamże, s. 61.

19 Por. M. Thiele, Geistliche Beredsamkeit. Reflexionen zur Predigtkunst, Stuttgart 2004, s. 134-135. 
powiadaniu słowa Bożego? Moja odpowiedź jest pozytywna, jakkolwiek na przestrzeni wieków stosunek kaznodziejów do stosowania humoru na ambonie nie był jednoznaczny. Ambiwalencja stanowisk w tym względzie wynika z faktu, że nie wszyscy odnajdują humor w Piśmie Świętym jako podstawowym źródle przepowiadania i nie wszyscy dostrzegają humor Pana Jezusa. Zarówno zwolennicy, jak i przeciwnicy humoru w przepowiadaniu znajdują dla siebie argumenty zarówno w Piśmie Świętym jak i w Tradycji patrystycznej. Najpierw przyjrzymy się argumentom przeciwników, a potem przytoczymy argumenty zwolenników.

\section{ARGUMENTY PRZECIWKO STOSOWANIU HUMORU W PRZEPOWIADANIU}

Jako argumenty przeciwko stosowaniu humoru w przepowiadaniu przytaczane są argumenty biblijne, wypowiedzi ojców Kościoła oraz teologów.

\subsection{BIBLIA, OJCOWIE KOŚCIOŁA I TEOLODZY}

Przeciwnicy stosowania humoru w przepowiadaniu utrzymują, że Jezus nigdy się nie śmiał i że Ojcowie Kościoła napominali surowo przeciwko wszelkim rozrywkom i żartom. Owszem, przyznają, że Chrystus rozradował się w Duchu, więc miał jakąś wewnętrzną radość, ale nie wyrażał jej śmiechem na zewnątrz ${ }^{20}$. Ewangelie nigdy nie mówią o śmiechu, a nawet o uśmiechu Jezusa. Mówią natomiast dwukrotnie o tym, że Jezus zapłakał: nad Jerozolimą i nad grobem Łazarza, a więc nad miastem i nad swoim przyjacielem ${ }^{21}$.

Wymowną przyczyną deprecjonowania humoru w Ewangeliach jest nacisk, jaki ich autorzy położyli na opisach Męki Pana Jezusa. Wszyscy czterej ewangeliści zgodnie ze swoją teologią przedstawili szczegółowo wydarzenia paschalne, które stanowiły zwieńczenie życia i nauczania Jezusa

20 B.M. Berchmans, Umorismo, s. 1640.

${ }^{21}$ W.J. Burghardt, Preaching. The Art and the Craft, New York-Mahwah 1987, s. 160 . 
Chrystusa. Dla apostołów i pierwszych chrześcijan wręcz niepojętą była myśl o cierpiącym Synu Bożym. Lud oczekiwał Mesjasza przychodzącego w chwale, który zakończy rzymskie panowanie w Palestynie. Tymczasem Jezus został aresztowany, osądzony i ukrzyżowany przez rzymskich okupantów. Dostarczenie odpowiedzi na pytanie, dlaczego Mesjasz musiał cierpieć i umrzeć haniebną śmiercią było kluczowym zadaniem ewangelistów $^{22}$. Dlatego też skoncentrowali oni swoją uwagę na Pasji. Owa właśnie konieczność wyjaśnienia sensu cierpień Jezusa sprawia, że wątki smutne mogą przesłaniać radosne wydarzenia z Jego życia ${ }^{23}$.

Najwymowniejszym cytatem przytaczanym przez przeciwników humoru w homilii czy kazaniu są przestrogi, „biada” w Jezusowym Kazaniu na Górze: „Biada wam, którzy się teraz śmiejecie, ponieważ płakać będziecie" (Łk 6,25). W komentarzu do przytoczonego tekstu Ewangelii według św. Łukasza, św. Ambroży (ok. 339-397) podkreślił, że ci, którzy w życiu doczesnym śmieją z powodu rzeczy światowych będą cierpieli w świecie przyszłym. Do ostrożności podczas rekreacji wzywał św. Augustyn (354-430): „Uważajmy, kiedy szukamy chwili wytchnienia umysłu, abyśmy nie utracili całej harmonii naszych dobrych dzieł" ${ }^{24}$.

Badając pojęcie zabawy w myśli greckiej, rzymskiej i wczesnochrześcijańskiej, Hugo Rahner zauważył, że Arystoteles zachęcał ludzi do zachowywania równowagi między humorem a powagą. Natomiast wielu pisarzy wczesnochrześcijańskich zdecydowanie preferowało poważne podejście do życia. Uzasadnieniem takiego podejścia była chęć przeciwstawienia się pokusom świata i Szatanowi ${ }^{25}$. Święty Paweł polecił chrześcijanom unikać wszystkiego, co „niedorzeczne” (Ef 5,4), a według przekładu Alfreda Marshalla: „nierozsądnych rozmów lub żartów”26. Klemens z Aleksandrii przestrzegał przed „słowami żartobliwymi i nieprzystojnymi”27.

\footnotetext{
22 Por. J. Martin, Między niebem a radością, s. 57.

${ }^{23}$ Por. Tamże, s. 60.

${ }^{24}$ B.M. Berchmans, Umorismo, s. 1640.

${ }^{25}$ Por. J. Martin, Między niebem a radościa, s. 46; zob. H. Rahner, Man at Play,
} Herder and Herder, New York 1967.

26 The Interlinear Literal Translation of the Greek New Testament, Zondervan, Grand Rapids 1975; cyt. za: J. Martin, Między niebem a radościa, s. 46 i 300.

${ }^{27}$ J. Martin, Między niebem a radością, s. 46. 
Prawdopodobnie nikt inny nie wypowiedział tak zdecydowanych słów przeciwko humorowi jak św. Jan Chryzostom (ok. 350-407). Według niego, „Ten świat nie jest teatrem, w którym moglibyśmy się śmiać; nie gromadzimy się $\mathrm{w}$ tym celu, aby wybuchać śmiechem, ale po to, by zapłakać nad własnymi grzechami [...]. To nie Bóg daje nam okazję do rozrywki, ale diabeł". W tym samym duchu niektóre ruchy ascetyczne identyfikowały wszelką przyjemność z grzechem ${ }^{28}$. Krytyczny stosunek do humoru podtrzymywany był przez tradycję monastyczną opartą na regule św. Bazylego Wielkiego (329-379) ${ }^{29}$.

Kontynuatorem tego rodzaju poglądów na przełomie XVII i XVIII w. był François Salignac Fénelon (1651-1715). W Dialogach o elokwencji radził kaznodziejom: „Gdy nauczasz w kościele, nie wywołuj u słuchaczy aplauzu, ale lament. Niech pochwałą dla ciebie będą łzy słuchaczy. Mowa kaznodziei ma być wypełniona Pismem Świętym. Nie bądź deklamatorem, ale prawdziwym nauczycielem misteriów Boga" ${ }^{30}$.

Jezuita Daniel J. Harrington, profesor Nowego Testamentu na Uniwersytecie Bostońskim przekazał zabawną, a przy tym prawdziwą historię ukazującą, jak trudno jest niektórym chrześcijanom - nawet zawodowo zajmującym się kwestiami teologicznymi - dopuścić na myśl, że Pan Jezus miał poczucie humoru. „Otóż któregoś razu w jednym z chrześcijańskich dzienników przygotowano recenzję książki zatytułowanej Comic Christ (Komiczny Chrystus). Redaktor uznał, że ten tytuł to musi być pomyłka. Jak Jezus może być komiczny? Redaktor zmienił więc tytuł na Cosmic Christ (Kosmiczny Chrystus)" ${ }^{11}$. Komentując tę opowieść James Martin, stwierdza, że do dzisiaj wielu ma trudności z przyjęciem wizerunku radosnego Jezusa, Zbawcy z uśmiechem, czy wręcz komicznego Chrystusa ${ }^{32}$.

${ }^{28}$ B.M. Berchmans, Umorismo, s. 1640; G.A. Arbuckle, Laughing with God. Humor, Culture, and Transformation, Collegeville 2008, s. XIII.

${ }^{29}$ Por. W.J. Burghardt, Preaching, s. 159.

${ }^{30}$ Dialogues on Eloquence, wyd. 1951, s. 153; cyt. za: A.I. Hoch, Fénelon François Salignac de la Mothe, $\mathrm{w}$ : Concise Encyclopedia of Preaching, red. W.H. Willimon, R. Lisher, Louisville 1995, s. 137.

${ }^{31}$ J. Martin, Między niebem a radościa, s. 45.

32 Por. tamże. 


\subsection{KRYTYCZNE STANOWISKO TEOLOGÓW REFORMACJI WOBEC HUMORU}

Bardzo krytycznie do humoru na ambonie odnosiły się wspólnoty eklezjalne wyrosłe $\mathrm{z}$ Reformacji, jakkolwiek sam Marcin Luter (1483-1546) nie stronił od sarkazmu. Krytykując jakość współczesnego sobie przepowiadania w Kościele, ubolewał w 1533 r., że „Po odczytanym tekście Ewangelii, kaznodzieje prowadzą słuchaczy do krainy baśni: jeden głosi na podstawie Arystotelesa i ksiąg pogańskich, inny na kanwie dekretów papieskich. Jeden opowiada o swym zakonie, inny o kaczkach, jeszcze inny o mleku... Słowem, to sztuka, w której nikt nie trzyma się tekstu Dobrej Nowiny"33. Inny znaczący przedstawiciel ruchu reformatorskiego, założyciel metodystów, John Wesley (1703-1791) radził kaznodziejom, aby ich całe przemówienie było podniosłe i poważne ${ }^{34}$.

Protestancki teolog, Martin Marty uznał, że „Hilaritas nie jest jednym $\mathrm{z}$ atrybutów etosu protestanckiego" ${ }^{35}$. Szukając zaś powodu, dla którego w protestantyzmie, zwłaszcza amerykańskim, panuje awersja do humoru, wyjaśnił, „że nacisk na powagę w tradycji amerykańskiego protestantyzmu może mieć związek z przekonaniem, że wszystko, co robisz, musi się do czegoś «przyczyniać». [...] w pewnych fragmentach protestanckiego DNA zapisane jest pewne ponuractwo. [...] mówi się przecież o protestanckim etosie pracy, a nie zabawy"36.

Jak głęboko zakorzeniony był dystans do humoru we wspólnotach protestanckich, świadczy wypowiedź Karola Bartha (1886-1968). Opowiadał on, że w listopadzie 1916 r. spotkał bardzo pobożnego człowieka, który był przekonany, iż chrześcijanin nie powinien nigdy żartować37. Trzydzieści lat później, w 1946 r. inny wielki teolog protestancki, Reinhold Niebuhr (1892-1971) zaprezentował łagodniejsze i bardzo wyważone stanowisko wobec humoru na ambonie. Mówił, że w przestrzeni kościelnej

${ }_{33}$ Winkelmesse und Pfaffenweihe, cyt. za: R.P. Waznak, The Catechism and The Sunday Homily, "America" 171 (1994) 12, s. 21.

${ }^{34}$ W.H. Willimon, Humor, w: Concise Encyclopedia of Preaching, red. W.H. Willimon, R. Lisher, Louisville 1995, s. 263.

35 J. Martin, Między niebem a radością, s. 176.

36 Tamże, s. 177-178.

${ }^{37}$ U. Homann, Das Christentum und der Humor, http://www.ursulahomann.de/ DasChristentumUndDerHumor/komplett.html (dostęp: 12.01.2009). 
jest miejsce na humor, ale też jest miejsce, gdzie go nie powinno być: „Jest śmiech w przedsionku kościoła, echo śmiechu w samej świątyni, ale tylko wiara i modlitwa, żaden śmiech, w miejscu najświętszym" ${ }^{38}$.

\section{ARGUMENTY ZA WYKORZYSTANIEM HUMORU W PRZEPOWIADANIU}

Jednak o wiele bardziej przekonujące są argumenty rzeczników wykorzystania humoru na ambonie. Również one wyprowadzane są z Biblii, tekstów patrystycznych oraz wypowiedzi teologów. Dodatkowego argumentu dostarcza ponadto marketing i retoryka.

\subsection{BIBLIA}

W samej Biblii znajdujemy historie przepełnione humorem. Przykładem jest chociażby historia Abrahama i Sary, którym dopiero w bardzo podeszłym wieku urodził się syn. Gdy Sara usłyszała, że będzie matką, roześmiała się (por. Rdz 18,11-12.15). Doza humoru - pomimo powagi sytuacji - zawarta jest w odpowiedzi Szifry i Puy, położnych egipskich, które wbrew zakazowi króla egipskiego nie zabijały dzieci izraelskich, twierdząc: „Kobiety hebrajskie nie są podobne do Egipcjanek, one są zdrowe, toteż rodzą wcześniej, zanim zdoła do nich przybyć położna" (Wj 1,19). Pełna humoru jest też rozmowa Balaama $\mathrm{z}$ jego oślicą (Lb 22,5-31).

Według jezuity, Waltera J. Burghardta (1914-2008) humor widoczny jest w wyborach, jakich dokonywał Bóg realizując swój plan zbawienia. Autor pyta: „Kto mógłby przypuszczać, że Bóg zamiast uczciwego Ezawa wybierze sprytnego i przebiegłego Jakuba; albo też, że Bóg wybierze Noego, który nie gardził winem i opróżniał butelki jedną po drugiej; albo Mojżesza, który zabił Egipcjanina... Ze wszystkich narodów Bóg wybrał dla siebie lud święty spośród Żydów, o których mówi się, że są tak jak

${ }^{38}$ R. Niebuhr, Discerning the Signs of the Times, 1946, s. 130-131; cyt. za: W.H. Willimon, Humor, w: Concise Encyclopedia of Preaching, red. W.H. Willimon, R. Lisher, Louisville 1995, s. 262. 
każdy inny, ale o wiele bardziej. Bardziej religijni, gdy byli religijni i bardziej zeświecczeni, gdy byli zeświecczeni - jakby wymyślili świeckość” ${ }^{39}$.

Obok humorystycznych wydarzeń obecne są w Biblii humorystyczne kalambury - żarty słowne. Jako przykład może posłużyć zagadka Samsona: „Z tego, który pożera, wyszło to, co się spożywa, a z mocnego wyszła słodycz" (Sdz 14,14). Konkurenci Samsona, Filistyni zdobyli rozwiązanie zagadki za pośrednictwem jego żony i odpowiedzieli za pomocą innej zagadki: „Cóż słodszego niż miód, a cóż mocniejszego niż lew. Odpowiedział im: Gdybyście nie orali moją jałowicą, nie rozwiązalibyście mojej zagadki” (Sdz 14,18).

Kalambury stosował również Pan Jezus, czego przykładem jest fragment Kazania na Górze w aramejskim brzmieniu: „Nie dawajcie psom tego, co święte, i nie rzucajcie swych pereł przed świnie" (Mt 7,6). Humor widoczny jest również w przypowieściach Jezusa. Ich analiza pozwoliła autorowi Słownika kultury biblijnej, Johnowi Pilchowi stwierdzić, że „Jezus miał dosadne poczucie humoru" ${ }^{\prime 0}$.

To prawda, że ewangeliści byli bardzo powściągliwi w zakresie opisu fizycznych zachowań Jezusa. Owszem, św. Łukasz zanotował, że "Jezus rozradował się w Duchu Świętym" (Łk 10,21), więc miał jakąś wewnętrzną radość. Czy jednak ta wewnętrzna radość nie była w żaden sposób wyrażona na zewnątrz? ${ }^{41}$. Czy z ludzkich reakcji znał tylko łzy? Czy na weselu w Kanie Galilejskiej mógł pozostać ponurym, gdy wszyscy wokół cieszyli się i pili niemałe ilości wina?

Twierdzenie jakoby Chrystus nie miał poczucia humoru i nie śmiał się godzi nie tylko w Jego inteligencję, ale w ogóle podważa Jego człowieczeństwo, a przez to graniczy z herezją doketyzmu, utrzymującego, że ciało Jezusa było tylko podobne do ludzkiego. Według Waltera J. Burghardt’a, chrześcijanie za nadto podkreślają bóstwo Chrystusa kosztem Jego człowieczeństwa, traktując je jako nie do końca realne albo do tego stopnia doskonałe, że nie było w Nim miejsca na działanie nieplanowane, na żadne spontaniczne reakcje. Rodzi się jednak pytanie, czy Chrystus,

39 W.J. Burghardt, Preaching, s. 162.

40 J.J. Pilch, Słownik kultury biblijnej, Częstochowa 2004, s. 54. Więcej na temat humoru w Biblii zob. tamże, s. 49-55.

${ }^{41}$ W.J. Burghardt, Preaching, s. 159. 
zanim zapłakał nad Jerozolimą (por. Łk 19,41), dokładnie przemyślał to, że będzie płakał? Czy podjął świadomą decyzję, że chce zapłakać? Nie. Reagował jak człowiek ${ }^{42}$. Miał niezwykłą bystrość umysłu. W niezwykle błyskotliwy sposób omijał pułapki słowne zastawiane na Niego przez faryzeuszy i uczonych w Piśmie. Po mistrzowsku posługiwał się słowem. A zatem jako inteligentny, błyskotliwy człowiek miał też poczucie humoru. To prawda, że nie znajdziemy w Nowym Testamencie wyraźnego dowodu, że Jezus się uśmiechał, ale brak dowodu nie jest dowodem braku uśmiechu na twarzy Jezusa.

Autor Listu do Hebrajczyków stwierdził o Nim, że stał się do nas podobny we wszystkim oprócz grzechu (por. Hbr 4,15). Nie oznacza to oczywiści, że Jezus śmiał się wtedy, kiedy Jego rodacy chcieli wyrzucić Go z Nazaretu i strącić z góry, na której zbudowane było ich miasto. Z pewnością nie śmiał się w ogrodzie Getsemani. Nie umierał z uśmiechem na ustach, jak to przedstawia na przykład rzeźba konającego Chrystusa zatytułowana Christ sourian czyli uśmiechnięty Chrystus z ok. XII wieku przechowana $\mathrm{w}$ opactwie Lérins we Francji ${ }^{43}$. Bywają w życiu chwile, w których człowiek nie ośmiela się śmiać, bo sytuacja na to nie pozwala. Ale trzeba powiedzieć, że Jezus był w pełni człowiekiem. Przeszedł przez życie dobrze czyniąc, działając jak człowiek. Pociągnął za sobą wielu naśladowców. Był atrakcyjny nie tylko dla rybaków, setników, dla kobiet, ale też dla dzieci i ludzi bardzo prostych. Nie mógłby pociągnąć za sobą tak wielu uczniów, gdyby Jego twarz przypominała jedynie o sądzie ostatecznym, gdyby nigdy nie pojawiał się na niej uśmiech ${ }^{44}$.

Argumenty na temat humoru w Ewangeliach zostały potwierdzone przez naukowców. W latach 60. XX w. Elton Trueblood (†1994), profesor filozofii w College Earlham w stanie Indiana napisał książkę The Humor of Christ. We wprowadzeniu do niej wyjaśnił, że inspiracją do napisania książki na temat humoru Jezusa stało się doświadczenie lektury Biblii z czteroletnim synem. Chociaż rodzice z powagą czytali siódmy rozdział Ewangelii według św. Mateusza, ku ich zaskoczeniu dziecko w pewnym momencie wybuchło śmiechem. Jako bardzo zabawne wydały się mu

\footnotetext{
42 Tamże, s. 160.

43 Tamże, s. 159.

${ }^{44}$ Tamże, s. 160.
} 
słowa, że człowiek może zajmować się drzazgą w oku bliźniego, gdy belka tkwi w jego oku (por. Mt 7,3-5) ${ }^{45}$. „Można wyobrazić sobie podobny scenariusz także w przypadku innych przesadnych sformułowań, np. o wielbłądzie i uchu igielnym (Mk 10,25), o przecedzaniu komara i połykaniu wielbłąda (Mt 23,24), o myciu zewnętrznej strony kubka i pozostawianiu brudu w środku (Mt 23,25)"46. Elton Trueblood zamyka książkę apendyksem zawierającym 30 humorystycznych fragmentów Ewangelii synoptycznych ${ }^{47}$. Z kolei Joseph A. Grassi, koncentrując uwagę na humorze w Ewangelii według św. Łukasza, dostrzega go wszędzie tam, gdzie Boży plan jest realizowany przez słabych ludzi, a więc w sposób tak paradoksalny, nieoczekiwany i zdumiewający, że może to tylko budzić u ludzi radosny śmiech ${ }^{48}$. Jeśli nie dostrzegamy humoru w Nowym Testamencie, to po części dlatego, że znamy te teksty zbyt dobrze, znamy też pointę wielu przypowieści, a zatem osłabiony jest typowy dla humoru efekt zaskoczenia ${ }^{49}$.

Poza tym nie można zapominać, że Jezus wychowywał się w kulturze żydowskiej, w której humor był czymś naturalnym. Przekazywane ustnie hagady, spisane później w Talmudzie są pełne humoru. Trudno nie zgodzić się z założycielem chasydyzmu, Israelem ben Eliezerem, znanym jako Baal Schem Tov (1700-1760), który mawiał, że Bóg pragnie ludzi radosnych, szatan smutnych. Toteż psalmista wzywał całe stworzenie, by chwaliło Boga z radością (por. Ps 66,1; 107,22). Humor jest częścią tradycji żydowskiej, a Jezus w niej wzrastał ${ }^{50}$.

\subsection{TEOLODZY I PAPIEŻE}

Argumenty za wykorzystaniem humoru w przepowiadaniu znajdziemy zarówno u Ojców Kościoła, jak i u wybitnych teologów, dawnych

45 Tamże, s. 160-161.

${ }^{46}$ J.J. Pilch, Słownik kultury biblijnej, Częstochowa 2004, s. 53.

47 W.J. Burghardt, Preaching. The Art and the Craft, New York-Mahwah 1987, s. 161 .

48 Tamże, s. 161.

49 Por. J. Martin, Między niebem a radością, s. 47.

${ }^{50}$ U. Homann, Das Christentum und der Humor, http://www.ursulahomann.de/ DasChristentumUndDerHumor/komplett.html (dostęp: 12.01.2009). 
i współczesnych. I tak na przykład, komentując Arystotelesa, św. Tomasz z Akwinu nawiązał najpierw do wypowiedzi św. Augustyna, który zachęcał: „Chciałbym, żebyś zaoszczędził swoje siły, energię, ponieważ dobrze jest, aby człowiek mądry odpoczywał od czasu do czasu, dając umysłowi nieco odpoczynku od spraw, którymi się zajmuje". Następnie zaś Akwinata dodał, że jest coś dobrego w humorze, że jest on przydatny w życiu. Podobnie bowiem jak człowiek od czasu do czasu potrzebuje odpoczynku, tak samo umysł ludzki potrzebuje czasami rozrywki i odpoczynku od intensywnej koncentracji na poważnych argumentach. A sposobem na osiągnięcie owego intelektualnego wytchnienia jest właśnie humor ${ }^{51}$.

Do pielęgnowania humoru zachęcał swych duchowych braci św. Ignacy Loyola. Mawiał im, że cała postawa braci jezuitów, ich zachowanie powinno wyrażać raczej radość niż smutek ${ }^{52}$.

W bliższych nam czasach papież Paweł VI wydał adhortację $O$ radości chrześcijańskiej, Gaudete in domino ${ }^{53}$. Wprawdzie w ogóle nie używa w niej słowa humor ani związanych z nim takich wyrazów, jak: komizm, satyra, ironia, żart, dowcip. Natomiast ponad 150 razy mówi o radości, a 43 razy o Duchu Świętym. Prawdziwa chrześcijańska radość jest owocem Ducha Świętego, a więc skutkiem łaski. Łaska zaś buduje na naturze i człowiek jest zaproszony do współpracy z nią. Poczucie humoru sprzyja działaniu Ducha Świętego w człowieku i w zgromadzeniu ludu Bożego.

Humor charakteryzował wiele spontanicznych wypowiedzi Jana Pawła II. Można wręcz powiedzieć, że papież z Polski był mistrzem humoru sytuacyjnego - sitcomu (ang. situation comedy). Wiele epizodów z jego życia można opowiadać z uśmiechem. Dla przykładu, tym, którzy krytykowali zbudowanie basenu w letniej rezydencji papieskiej w Castel Gandolfo, odpowiadał: „Znacznie tańsze jest zbudowanie basenu niż wybranie nowego papieża!"54. Wiele rozgłosu zdobyła wypowiedź Jana Pawła II w czasie nabożeństwa ekumenicznego we wrocławskiej Hali Ludowej dnia 31 maja 1997 r. W trakcie wystąpienia papież zaczął kichać. Po pierwszym kichnięciu czterotysięczne zgromadzenie zachowało ciszę,

${ }^{51}$ B.M. Berchmans, Umorismo, s. 1640.

${ }^{52}$ W.J. Burghardt, Preaching, s. 164.

${ }^{53}$ Paweł VI, Adhortacja o radości chrześcijańskiej, Gaudete in domino (9.05.1975), „Wiadomości Archidiecezjalne Katowice” 8 (1988), s. 313-336.

${ }^{54}$ B.M. Berchmans, Umorismo, s. 1640. 
ale drugie kichnięcie - zostało nagrodzone brawami. Papież z figlarnym uśmiechem na twarzy powiedział: „Okazuje się, że kichnięcie może mieć sens ekumeniczny i służyć sprawie pojednania”. Wywołał w ten sposób salwę śmiechu, a owo spotkanie pięknie wpisało się w historię ekumenizmu.

Pozytywnie na temat roli humoru wypowiedział się papież Benedykt XVI. W wywiadzie dla „The Tablet” powiedział swobodnym tonem: „Uważam, że bardzo istotne jest dostrzeganie radosnej strony życia, a także nie traktowanie wszystkiego zbyt tragicznie - jest to szczególnie konieczne w przypadku mojej posługi” ${ }^{55}$.

Gerald A. Arbuckle, autor książki, Laughing with God. Humor, Culture, and Transformation ${ }^{56}$ zawarł $\mathrm{w}$ jej wstępie osobiste wyznanie: „Nie potrafiłbym przetrwać ciemnych stron posługi kapłańskiej w ostatnich czterdziestu latach, gdyby ojciec i matka nie nauczyli mnie mądrości humoru. Na początku mojej posługi kapłańskiej ojciec mawiał: «Gerard nie zapominaj, że Bóg rządzi i kieruje wszystkim nie ty». Pomagały mi te słowa, gdy myślałem, że zbawienia świata zależy ode mnie”.

Zdaniem kardynała Waltera Kaspera, humor jest jednym z ważnych elementów chrześcijańskiej wiary. Kardynał twierdzi jednocześnie, że jednym z zarzutów, jakie można podnieść przeciwko współczesnemu duszpasterstwu i współczesnej teologii jest brak humoru ${ }^{57}$. W podobnym duchu, ale obszerniej, wypowiadał się wybitny kaznodzieja jezuicki W.J. Burghardt. Z charakterystycznym dla siebie dostojnym humorem pytał: „Czy Kościół nie jest nazbyt poważny?... Czy tylko powaga została ochrzczona? Czy śmiech jest pogański?... Kościół byłby na złej drodze, gdyby skazał śmiech na wygnanie z sanktuarium i pozostawił jedynie dla kabaretów i nocnych klubów" ${ }^{58}$. Przeciwstawiając się takim tendencjom, W.J. Burghardt nie stronił w swych homiliach od humoru, a w opracowaniach homiletycznych podkreślał, że towarzysząca humorowi radość jest manifestacją łaski Bożej. Humor świadczy o łasce, która działa w kaznodziei. Oczywiście, humor jest także darem natury, która stanowi podstawę

55 The Tablet 19 sierpnia 2006, s. 9; cyt. za: G.A. Arbuckle, Laughing with God, s. XIV.

${ }^{56}$ Collegeville 2008, s. XIV.

57 Tamże, s. XIII.

58 W.J. Burghardt, Preaching, s. 166. 
dla działania łaski ${ }^{59}$. Z dozą ironii W.J. Burghardt konstatował, że niektórzy kaznodzieje mają humor jedynie podczas pikników i przyjęć, natomiast na ambonie grzmią apokaliptycznym głosem surowości i patetyczną powaga $^{60}$. Tymczasem chrześcijański mówca powinien być przeniknięty radością, by mógł rodzić ją u innych i porywać ich do wiary w Chrystusa. Toteż humor wcale nie musi być na ambonie tylko wyjątkowym gościem. Ma prawo na niej się zadomowić. Albowiem „przyjmując nasze ludzkie ciało, Syn Boży przyjął, przeobraził i uświęcił nie tylko naszą duszę i zmysły, ale także naszą przeponę"61.

\subsection{POZYTYWNE STANOWISKO TEOLOGÓW REFORMACJI WOBEC HUMORU}

Również w środowisku protestanckich homiletów i kaznodziejów, oprócz przeciwników humoru, są jego protagoniści. W XIX w. za sprawą Henry’ego Warda Beechera (1813-1887) humor stał się cechą charakterystyczną przepowiadania północnoamerykańskiego ${ }^{62}$. Również Charles Haddon Spurgeon (1835-1892), określany mianem księcia anglojęzycznych kaznodziejów zabiegał o to, by jego kazania były pełne humoru i rodziły radość. Humor bowiem, według C.H. Spurgeona, ma charakter odkupieńczy i uświęcający ${ }^{63}$. Jeden $z$ największych teologów luterańskich XX w., niemiecki profesor uniwersytecki, a zarazem wybitny kaznodzieja Helmut Thielicke (1908-1986) jest autorem mało znanej w kręgach katolickich książki p.t. Spotkanie ze Spurgeonem. Thielicke zafascynował się baptystycznym kaznodzieją epoki wiktoriańskiej, dostrzegając w jego przepowiadaniu humor i radość ${ }^{64}$.

\subsection{MARKETING I RETORYKA}

Obok argumentów teologicznych dodatkowego uzasadnienia do stosowania humoru w przepowiadaniu dostarcza współczesny marketing

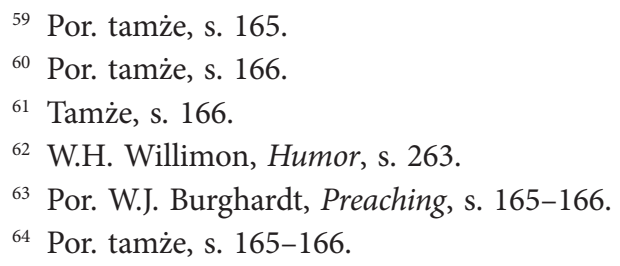


oraz retoryka. Specjaliści od reklamy i PR-u nader dobrze znają siłę humoru w społecznych relacjach. Humor jest jednym z ważnych elementów codziennej ludzkiej egzystencji. Przenika codzienne rozmowy, jest obecny w arcydziełach literatury i sztuki. Specjaliści od marketingu i reklamy chętnie wykorzystują humor, wiedząc, że można dzięki niemu przykuć uwagę publiczności do jakiegoś produktu. Toteż niemal w czterdziestu procentach reklam wykorzystana jest jakaś forma humoru. Również doradcy polityków i specjaliści od public relation zachęcają swych klientów, aby w publicznych wystąpieniach wykorzystywali dozę humoru ${ }^{65}$.

$\mathrm{W}$ jednym $\mathrm{z}$ opracowań na temat publicznych przemówień, zamieszczona jest rada, jak przekonująco przemawiać: „Nie bądź ponury. Uśmiechnij się... Ciepły uśmiech jest najbardziej uniwersalnym językiem. Nawet Twoi przeciwnicy trochę zmiękną, jak się do nich uśmiechniesz [...]. Z tym wiąże się sprawa poczucia humoru. Och, wiem doskonale, że nie jesteś go pozbawiony. Zresztą Frank Moore Colby w 1926 r. napisał: Większość ludzi raczej przyzna się do popełnienia morderstwa, do podpalenia, do tego, że mają sztuczną szczękę czy perukę, niż do braku poczucia humoru. A więc umówiliśmy się: wszyscy go mamy. A wiesz, co jest tego najlepszym sprawdzianem? Umiejętność śmiania się z samego siebie"66.

\section{PODSUMOWANIE}

Dobry humor pełni wiele użytecznych funkcji: dostarcza relaksu i wytchnienia, zmniejsza napięcia w relacjach społecznych, sprzyja zapamiętywaniu przekazywanych treści, zakładając że dotyczy tematu. Elementy humoru znajdujemy w Biblii, która jest podstawowym źródłem przepowiadania. Humorem przepełniona jest kultura żydowska, w której wzrastali i którą współtworzyli bohaterowie tak Starego, jak i Nowego Testamentu. Wiele wskazuje też na to, że Jezus, mając pełnię człowieczeństwa, był człowiekiem z dobrym poczuciem humoru. Ponadto zastosowanie humoru i przemawianie $\mathrm{z}$ uśmiechem jest bardzo zalecane

${ }^{65}$ B.M. Berchmans, Umorismo, s. 1641.

${ }^{66}$ Por. A. Wiszniewski, Jak przekonująco mówić i przemawiać, Warszawa-Wrocław 1994, s. 74-75. 
przez specjalistów od wystąpień publicznych. Skoro więc profesjonaliści od komunikacji społecznej wysoko cenią stosowanie humoru w wypowiedziach publicznych, głosiciele słowa Bożego nie powinni ignorować tego środka. Zwłaszcza, że Kongregacja ds. Duchowieństwa mobilizuje kapłanów, aby śmiało podejmowali pokojową konfrontację z profesjonalistami telewizji i radia, argumentując przy tym, iż orędzie chrześcijańskie „winno rozbrzmiewać w sposób zdecydowanie atrakcyjny”67.

Oczywiście, w przepowiadaniu może być wykorzystany tylko dobry humor, który nie jest wymierzony przeciwko komukolwiek. Ponadto powinien być on stosowany $\mathrm{z}$ umiarem, ponieważ konfiguracje komiczne w kazaniu czy homilii nie są celem samym w sobie, lecz pełnią rolę służebną wobec przekazywanych treści pierwszoplanowych. Toteż humor nie powinien być oderwany od głównego tematu, ale służyć jego lepszemu zrozumieniu. Poza tym o możliwości wykorzystania humoru decydują okoliczności przepowiadania, audytorium i poczucie humoru mówcy.

Streszczenie. Humor to zdolność dostrzeżenia inkongruencji czyli braku odpowiedniości. Pełni on wiele pożytecznych funkcji w życiu człowieka i społeczności ludzkich. Jego stosowanie zalecają specjaliści od komunikacji międzyludzkiej. Elementy humoru występują w Biblii. Istnieją też przekonujące argumenty, że Jezus miał wysokie poczucie humoru. $\mathrm{W}$ historii kaznodziejstwa istniały ambiwalentne postawy wobec wykorzystywania humoru na ambonie. Obecnie zarówno teolodzy, jak i specjaliści od retoryki i komunikacji międzyludzkiej zalecają przemawianie z humorem i uśmiechem, o ile tylko pozwalają na to okoliczności.

Słowa klucze: humor; przemawianie publiczne; relacje społeczne; kazanie; homilia.

Abstract. Preaching with Humor. Humor is the ability to discern incongruity or lack of suitability. It performs many useful functions in the human life and in the society. As far as the use of humor in preaching is concerned there are arguments pro

67 „Wszyscy przywykliśmy do słuchania i oglądania cenionych profesjonalistów telewizji i radia. Kapłan będący w szczególny sposób żywym ogniwem w procesie społecznego przekazu, staje wobec wiernych do pokojowej konfrontacji $\mathrm{z}$ innymi mediami. Dlatego orędzie, jakie przekazuje, winno rozbrzmiewać w sposób zdecydowanie atrakcyjny" - Kongregacja ds. Duchowieństwa, Kapłan głosiciel słowa, szafarz sakramentów i przewodnik wspólnoty $w$ drodze do trzeciego tysiaclecia chrześcijaństwa (19.03.1999), Tarnów [1999], s. 35. 
and contra. The article discusses both of them delivered from the Bible, the approach of the Fathers of the Church, theologians and the popes. One can find elements of humor in the Bible. There are convincing arguments that Jesus had a great sense of humor. In the history of preaching one may see the ambivalent approach to the use of humor in the pulpit. Currently however, both theologians and specialists in rhetoric and social communication recommend speaking with a smile and humor, as long as circumstances allow.

Keywords: humor; public speech; public relation; sermon; homily.

\section{BIBLIOGRAFIA}

Arbuckle G.A., Laughing with God. Humor, Culture, and Transformation, Liturgical Press, Collegeville, MN 2008.

Berchmans B.M., Umorismo, w: Dizionario di Omiletica, red. M. Sodi, A.M. Triacca, Velar, Torino-Bergamo 1998, s. 1640-1643.

Blackburn S., Oksfordzki słownik filozoficzny, Książka i Wiedza, Warszawa 2004.

Burghardt W.J., Preaching. The Art and the Craft, Paulist, New York-Mahwah, NJ 1987. Clowns without borders, http://www.clownswithoutborders.org/ (dostęp:20.06.2016).

Drakeford John W., Humor in Preaching, Publisher: Zondervan, Grand Rapids, Michigan, 1986.

Hoch A.I., Fénelon François Salignac de la Mothe, [w:] Concise Encyclopedia of Preaching, red. W.H. Willimon, R. Lisher, Louisville, KY 1995, s. 136-137.

Hofmeister A.S., „Jeder lacht in derselben Sprache“, „Die Tegespost“ 72 (2016), s. 8.

Homann U., Das Christentum und der Humor, http://www.ursulahomann.de/DasChristentumUndDerHumor/komplett.html (dostęp: 12.01.2009).

Janeczek S., Popielski K., Humor, w: Powszechna Encyklopedia Filozofii, t. 4, Polskie Towarzystwo Tomasza z Akwinu, red. A. Maryniarczyk i in., Lublin 2003, s. 669-672.

Kongregacja ds. Duchowieństwa, Kapłan głosiciel słowa, szafarz sakramentów i przewodnik wspólnoty $w$ drodze do trzeciego tysiąclecia chrześcijaństwa (19.03.1999), Biblos, Tarnów [1999].

Kucharska E., Przyczyna W., Czy podczas kazania jest miejsce na (u)śmiech, „Współczesna Ambona" 2 (2000), s. 184-189.

Martin J., Między niebem a radością. Humor i śmiech sednem życia duchowego, tłum. Edyta Stępkowska, Wydawnictwo św. Stanisława BM, Kraków 2012, s. 74.

Paweł VI, Adhortacja o radości chrześcijańskiej, Gaudete in domino (9.05.1975), „Wiadomości Archidiecezjalne Katowice" 8 (1988), s. 313-336.

Pilch J.J., Słownik kultury biblijnej, Częstochowa 2004.

Świat humoru, red. S. Gajda, D. Brzozowska, Wydawnictwo Uniwersytetu Opolskiego, Opole 2000.

Thiele M., Geistliche Beredsamkeit. Reflexionen zur Predigtkunst, Kohlhammer, Stuttgart 2004. 
Waznak R.P., The Catechism and The Sunday Homily, “America" 171 (1994) nr 12, s. 19-21.

Willimon W.H., Humor, w: Concise Encyclopedia of Preaching, red. W.H. Willimon, R. Lisher, Westminster John Knox Press, Louisville, KY 1995, s. 262-264.

Wiszniewski A., Jak przekonująco mówić i przemawiać, Warszawa-Wrocław 1994, Wydawnictwo Naukowe PWN, s. 74-75.

Wołyniec W., Humor, w: Leksykon duchowości katolickiej, red. M. Chmielewski, Wydawnictwo M, Lublin-Kraków 2002, s. 324-325. 